\title{
PROTEIN PROFILES IN WHEAT SEEDLINGS SUBJECTED TO DEHYDRATION STRESS
}

\author{
S. BAKALOVA ${ }^{1 *}-$ D. NEDEVA ${ }^{1}-$ J. MCKEE $^{2}$ \\ ${ }^{1}$ Acad. M. Popov Institute of Plant Physiology, Bulgarian Academy of Sciences, \\ Acad. G. Bonchev Street, Bldg. 21, 1113 Sofia, Bulgaria \\ ${ }^{2}$ NIAB, Huntingdon Road, CB3 OLE, Cambridge, UK \\ *Corresponding author \\ e-mail:ssabeva@bio21.bas.bg \\ (Received $17^{\text {th }}$ February 2007; accepted $12^{\text {nd }}$ March 2008)
}

\begin{abstract}
Changes in the soluble protein content, electrophoretic profiles of total and thermostable proteins and polypeptides in endosperms and roots of wheat seedlings germinated under optimal and stress conditions were investigated. Low and high temperature, $0.2 \mathrm{M} \mathrm{NaCl}, 0.5 \mathrm{M}$ sucrose, $30 \mu \mathrm{M} \mathrm{ABA}$ and $10 \mathrm{mM} \mathrm{H}_{2} \mathrm{O}_{2}$ were applied as stress factors and seeds germinated for 72 hours. The results obtained show that the time course of soluble protein mobilization at early germination depended on the nature of stress factors applied. The response to stress conditions was tissue specific. Low temperature stress elicited the greatest number and most intense total polypeptides in the roots of treated seedlings. High temperature most strongly influenced the thermostable polypeptide profile in endosperms. Content of a 25-kDa polypeptide related to cold tolerance increased in the roots of stressed seedlings. A thermostable polypeptide with a molecular weight of $42 \mathrm{kDa}$ was found in $\mathrm{H}_{2} \mathrm{O}_{2}$ stressed samples that was highly intensive and probably constitutes a stress specific response.
\end{abstract}

Keywords: ABA, germinating seeds, hydrogen peroxide, polypeptide spectra

\section{Introduction}

Proteins are compounds of fundamental importance for all functions in the cell [1]. It is well known that alteration of gene expression is always involved in preparing plants for an existence under stress. Protein variation is an essential part of plant response to environmental stress as well as for adaptation to environmental conditions [2],[3]. Under conditions of water deficit (dehydration) numerous processes are modified or impaired [4]. Water stress affects the protein levels of plants but the results of different authors are contradictory. Some authors show decreased protein levels under water stress [5],[6]. Others found an absence of deleterious effects of drought on protein levels [7]. Increasees in protein levels have also been reported [8]. One way of plants to tolerate abiotic stresses to some degree is by biosynthesis of so called stress proteins. Among them are dehydrins that accumulate in plants in response to ABA, low temperature and any other environmental influence that has a dehydration component, such as drought, salinity or extracellular freezing. [9]; [10], [11], [12].

A total of 73 genes encoding proteins were detected by Rabbani et al.[13] as stress inducible in rice. Among them 36, 62, 57, and 43 genes were induced by cold, drought, high salinity, and ABA, respectively. Fifteen genes responded to all four treatments.

The kinetics of mobilization of storage protein reserves in germinating seeds under optimal conditions has received considerable attention [14],[15]. The disturbances to this process under stressed conditions are less well understood [16] that means the role of protein mobilization in plant responce to different stresses is still not well understood. 
In order to determine whether seeds have evolved unique mechanisms to deal with environmental stresses we studied the effect of chronic stress on protein and polypeptide profiles in wheat seedlings subjected to different kind of abiotic stresses (extreme temperatures, salinity, osmotic shock). The common feature of all stresses applied is a dehydration component. ABA was used as a dehydration stress confirming standard.

\section{Materials and methods}

\section{Plant material and stress treatments}

Wheat seeds (Triticum aestivum L, Sadovo 1 cultivar) derived from field grown plants were used throughout the experiments. Sadovo 1 is a Bulgarian high productive cultivar resistant to pathogens, cold and drought. Seeds were germinated in filter paper rolls wetted with tap water, in darkness under optimal $\left(24^{\circ} \mathrm{C}\right.$ control), low $\left(10^{\circ} \mathrm{C}\right)$ or high $\left(38^{\circ} \mathrm{C}\right)$ temperature or in the presence of $0.2 \mathrm{M} \mathrm{NaCl}, 0.5 \mathrm{M}$ sucrose, $30 \mu \mathrm{M} \mathrm{ABA}$ or $10 \mathrm{mM} \mathrm{H}_{2} \mathrm{O}_{2}$, at $24^{\circ} \mathrm{C}$. The point at which water (or the treatment solution) was added to "dry seeds" was taken as time zero with respect to the duration of germination. Endosperms and roots of wheat seedlings grown for 72 hours were analyzed.

\section{Protein extraction}

Cell-free extracts from seedlings subjected to various treatments were analyzed for soluble protein content, electrophoretic protein and polypeptide spectra on nondenaturing and denaturing gels. Freshly harvested endosperms and roots samples were ground in $0.1 \mathrm{M}$ tris- $\mathrm{HCl}$ buffer, $\mathrm{pH}$ 7.1. The fresh material / buffer ratio was 1:3 for endosperms, and 1:10 for roots. The homogenate was centrifuged at $12000 \mathrm{x} \mathrm{g}$ for 30 $\min$ at $4{ }^{\circ} \mathrm{C}$. The supernatant was used for investigations. Protein samples were mixed with equal volumes of $40 \%$ sucrose solution (in the case of native PAGE) or sample buffer in (the case of SDS-PAGE) and stored at $-20^{\circ} \mathrm{C}$.

\section{Thermostable protein fraction}

The fraction of thermostable soluble proteins was obtained by the procedure of [17]. The supernatants with soluble proteins were boiled at $100^{\circ} \mathrm{C}$ for $10 \mathrm{~min}$, stored on ice and then centrifuged at top speed $(15000 \mathrm{x} \mathrm{g})$ in a microcentrifuge for $15 \mathrm{~min}$. The supernatants contained thermostable soluble proteins.

\section{Total protein content determination}

Protein content in the crude extracts was determined after TCA precipitation according to the method of Lowry et al. [18], using BSA as a standard.

\section{Native polyacrylamide gel electrophoresis}

Native PAGE in a $7.5 \%$ cylindrical gels with no reducing or denaturing agents was carried out according to the method of Davis [19]. One hundred $\mu \mathrm{g}$ of protein was loaded per tube and two mA per tube applied during electrophoresis. The gels were stained for protein with Coomassie brilliant blue R-250. The stained protein profiles were scanned densitometrically (ERI-10, Germany) at 600nm. Quantitative differences 
between protein spectra were evaluated by the intensity of the staining of bands and qualitative differences were estimated by the number and $\mathrm{Rm}$ values.

\section{$R m$}

(relative mobility) is the ratio between distance in centimeters from the start of the gel to the place of the protein band on the gel and the distance from the start of the gel to the front (marker dye bromphenol blue).

\section{SDS-PAGE}

was conducted on $12.5 \%$ acrylamide gels according to the description of Laemmli [20]. An electrophoresis calibration kit of MBI Fermentas was used to determine the molecular weight of proteins. Protein bands were detected by the silver staining outlined by Nesterenko et al. [21].

The data presented in this paper were obtained in three independent experiments.

\section{Results}

The results of total protein content in endosperms could be ordered from greatest to lowest as follows: low temperature $>$ sucrose $>\mathrm{NaCl}>\mathrm{H}_{2} \mathrm{O}_{2}>$ control $>\mathrm{ABA}>$ high temperature (Fig. 1).
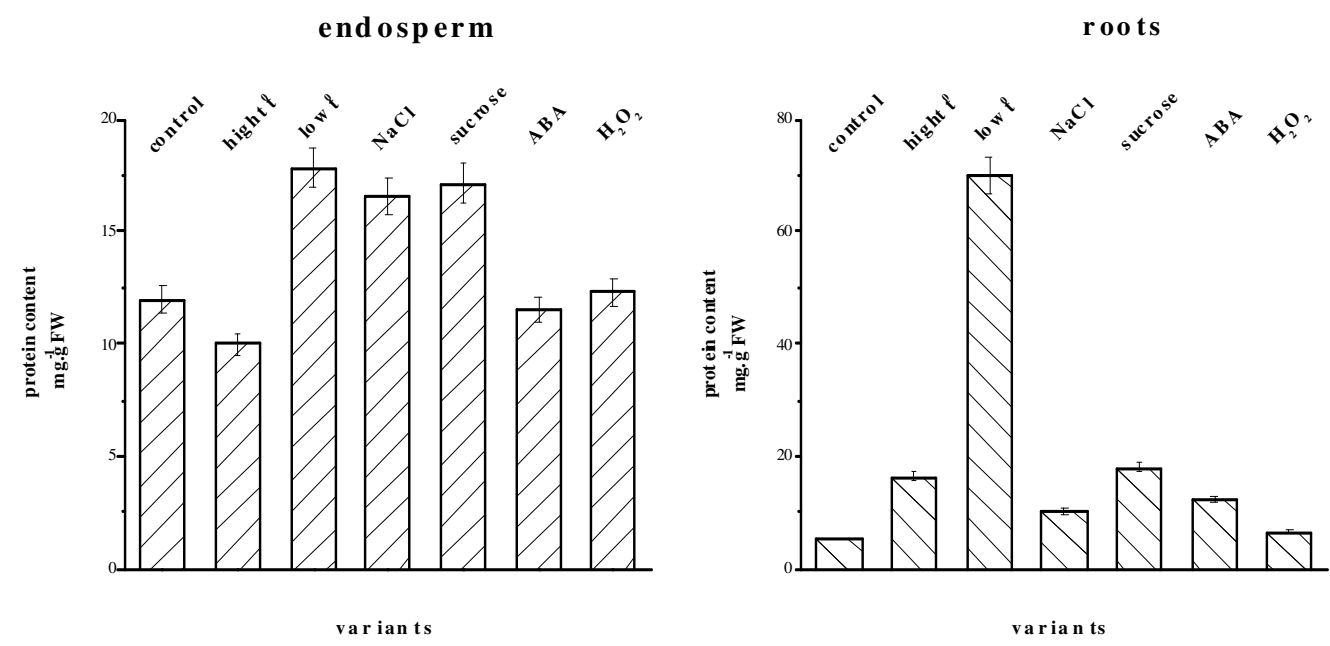

Figure 1. Protein content of endosperms and roots of 72 hour old wheat seedlings germinated under normal and stressed conditions

For root samples the order was: low temperature $>$ sucrose $>$ high temperature $>\mathrm{ABA}$ $>\mathrm{NaCl}>\mathrm{H}_{2} \mathrm{O}_{2}>$ control.

A total of 15 bands ranging in $\mathrm{Rm}$ values from 0.05 to 0.66 were observed in the spectrum of total soluble proteins in endosperms (Fig. 2-A). 
A
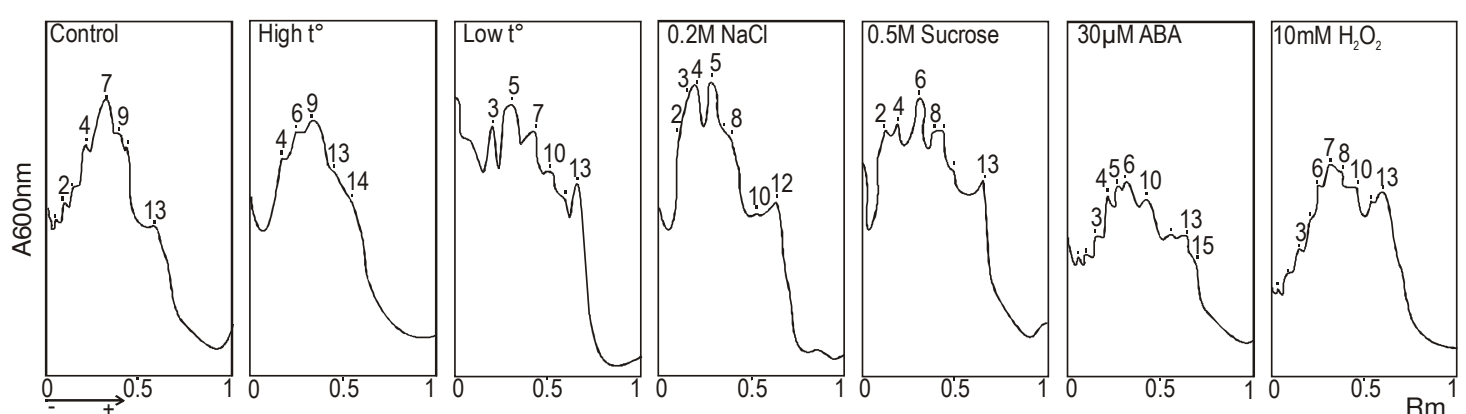

B
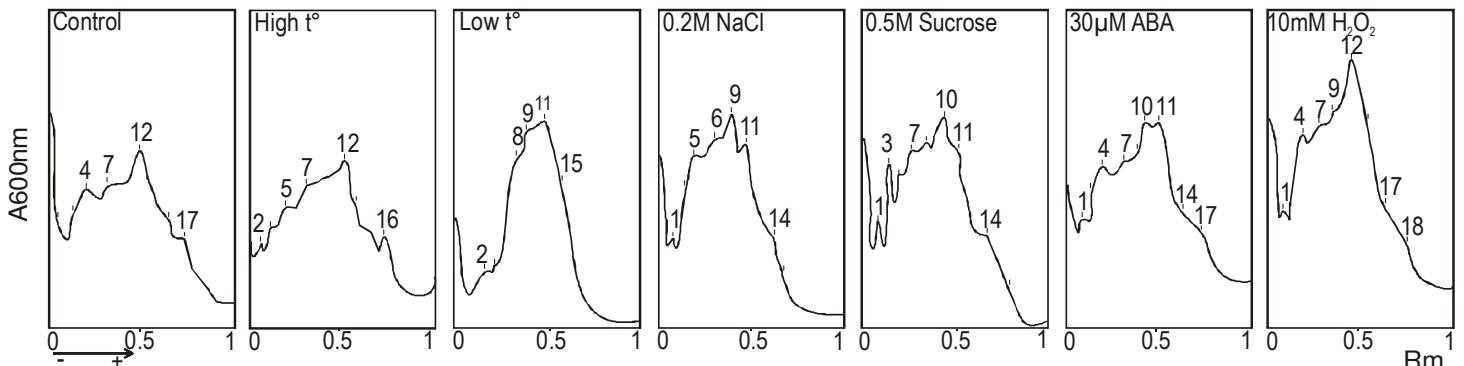

Figure 2. Electrophoresis of total soluble protein fractions on $7.5 \%$ polyacrylamide cylindrical gels after the method of Davis (1964). A-endosperms; B - roots

Individual treatments contained between 7 (low temperature) and 11 (ABA) different bands. The bulk of the protein across all treatments was located among moderate migrating bands ( $\mathrm{N} 4-10, \mathrm{Rm}$ 0.19-0.44). Eighteen protein bands were distinguished in root samples (Fig. 2-B). In contrast to the endosperm samples, in the roots quantitative as well qualitative differences in the total soluble protein spectra of seeds germinated under optimal and stressed conditions were also revealed. The lowest number of bands (6) was observed in the roots of seedlings germinated under low temperature. In the endosperm bands with lower electrophoretic mobility (N 3-9, Rm 0.14-0.39) prevailed, while in the roots moderate migrating bands dominated (N 9-12, Rm 0.39-0.52).

Electrophoretic spectra of thermostable proteins from endosperms of seedlings germinated under stress conditions varied in the quantity and quality of stained bands (Fig. 3).

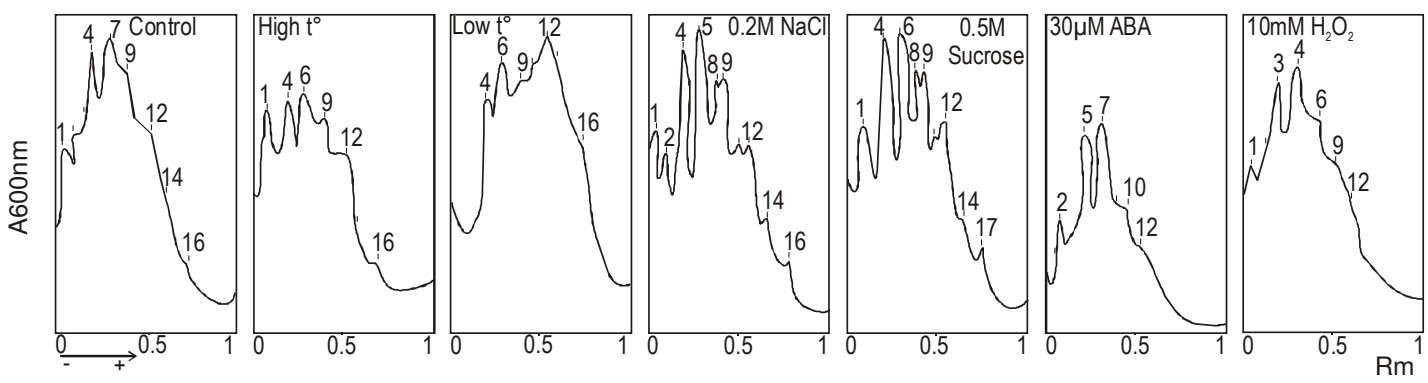

Figure 3. Electrophoresis of thermostable soluble protein fractions on $7.5 \%$ polyacrylamide cylindrical gels 
Most of the high intensive total protein bands in the endosperms were thermostable. In the endosperms of $\mathrm{NaCl}$ and sucrose germinated seedlings numerous sets of intensive bands were detected. In the roots of 72 hours old seedlings thermostable proteins were detected in trace amounts (data are not shown).

Figure 4 shows the greatest number of polypeptides (15) detected in endosperms germinated at low temperature, while the lowest number (10) was found in the endosperm of sucrose-germinated seedlings. The most significant difference however, was the induction of a $65 \mathrm{kDa}$ polypeptide in stressed endosperms that was absent in the control (Fig. 4).

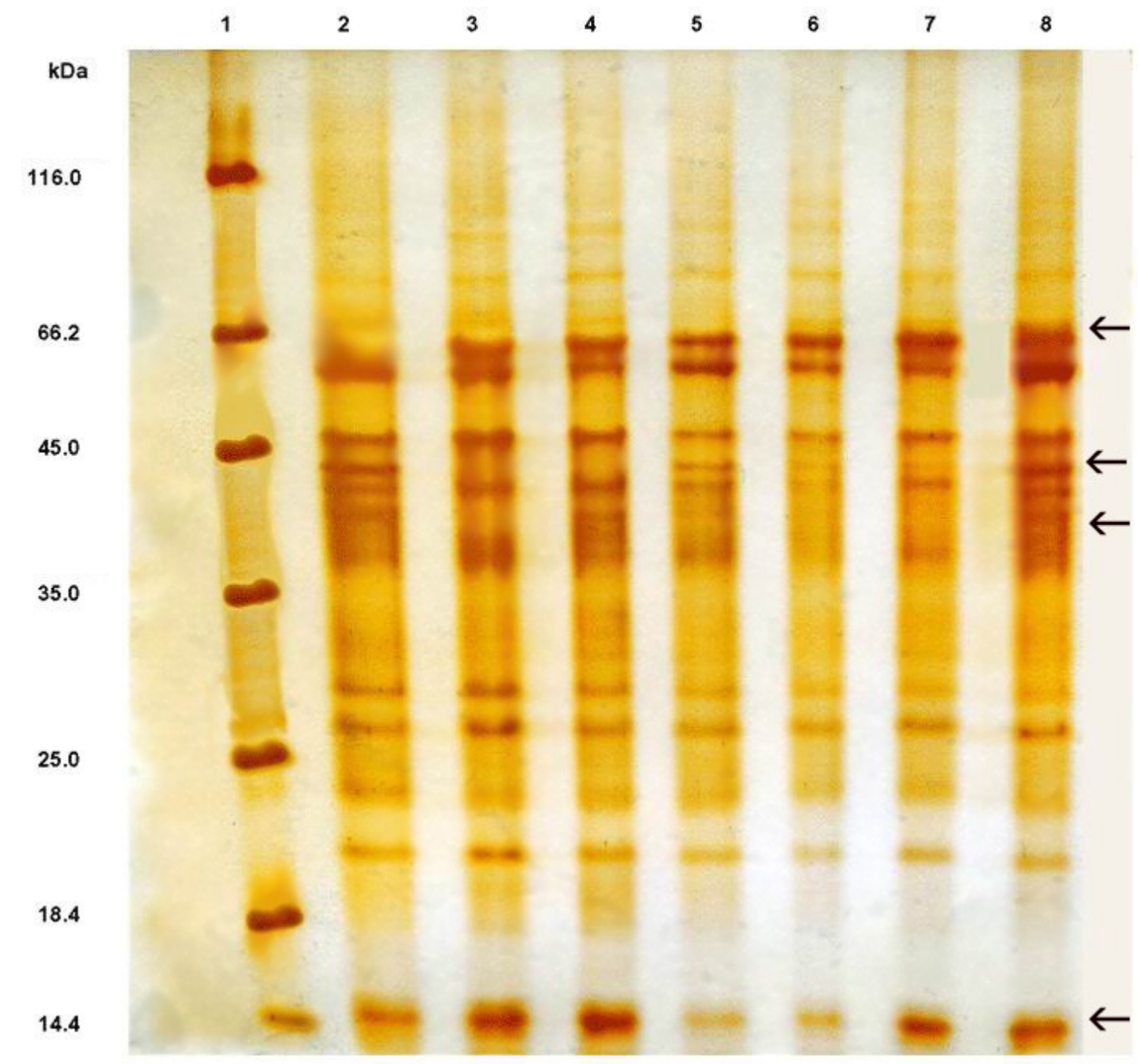

Figure 4. Polypeptide spectra (SDS-PAGE) of total soluble proteins in the endosperm of seedlings. Lane 1 -molecular mass markers (indicated on the left in $\mathrm{kDa}$ ) - $\beta$-galactosidase; bovine serum albumin; ovalbumin; lactate dehydrogenase; restriction endonuclease Bsp981; $\beta$ lactoglobulin; lysozyme, Lane 2 -control, Lane 3 -high temperature, Lane 4 -low temperature,

Lane 5-0.2 M NaCl, Lane 6-0.5 M sucrose, Lane 7-30 $\mu \mathrm{M} \mathrm{ABA,} \mathrm{Lane} \mathrm{8-10} \mathrm{mM} \mathrm{H}_{2} \mathrm{O}_{2}$. Twenty $\mu \mathrm{g}$ of total protein was loaded in each lane 
Polypeptides detected in the endosperms following germination segregated into four groups. The groups, based on molecular weight (MW) were: $65-62 \mathrm{kDa}, 46-38 \mathrm{kDa}, 29-$ $21 \mathrm{kDa}$ and $14.4 \mathrm{kDa}$. The high MW grouping was most intensive in the endosperm of $\mathrm{H}_{2} \mathrm{O}_{2}$ germinated seedlings followed in decreasing intensity by the high and low temperature, $\mathrm{NaCl}$ and $\mathrm{ABA}$ treatments. The most intensive polypeptides for the second grouping (46-38 kDa) were detected in $\mathrm{H}_{2} \mathrm{O}_{2}$, control, high and low temperature treatments, while the lowest intensity was in sucrose-germinated seedlings. The three most intensive polypeptide bands in the third MW grouping were found in the high temperature treated endosperms. Finally, the 14.4-kDa band was most intensive in high and low temperature, $\mathrm{ABA}$ and $\mathrm{H}_{2} \mathrm{O}_{2}$ treated endosperms, but was weak in the sucrose and $\mathrm{NaCl}$ treatments.

Between six and eight thermostable polypeptides were found in control endosperms and all stress treated endosperms. One very intensive thermostable polypeptide with MW 14.4 kDa was found in the endosperms of seedlings tested (Fig. 5).

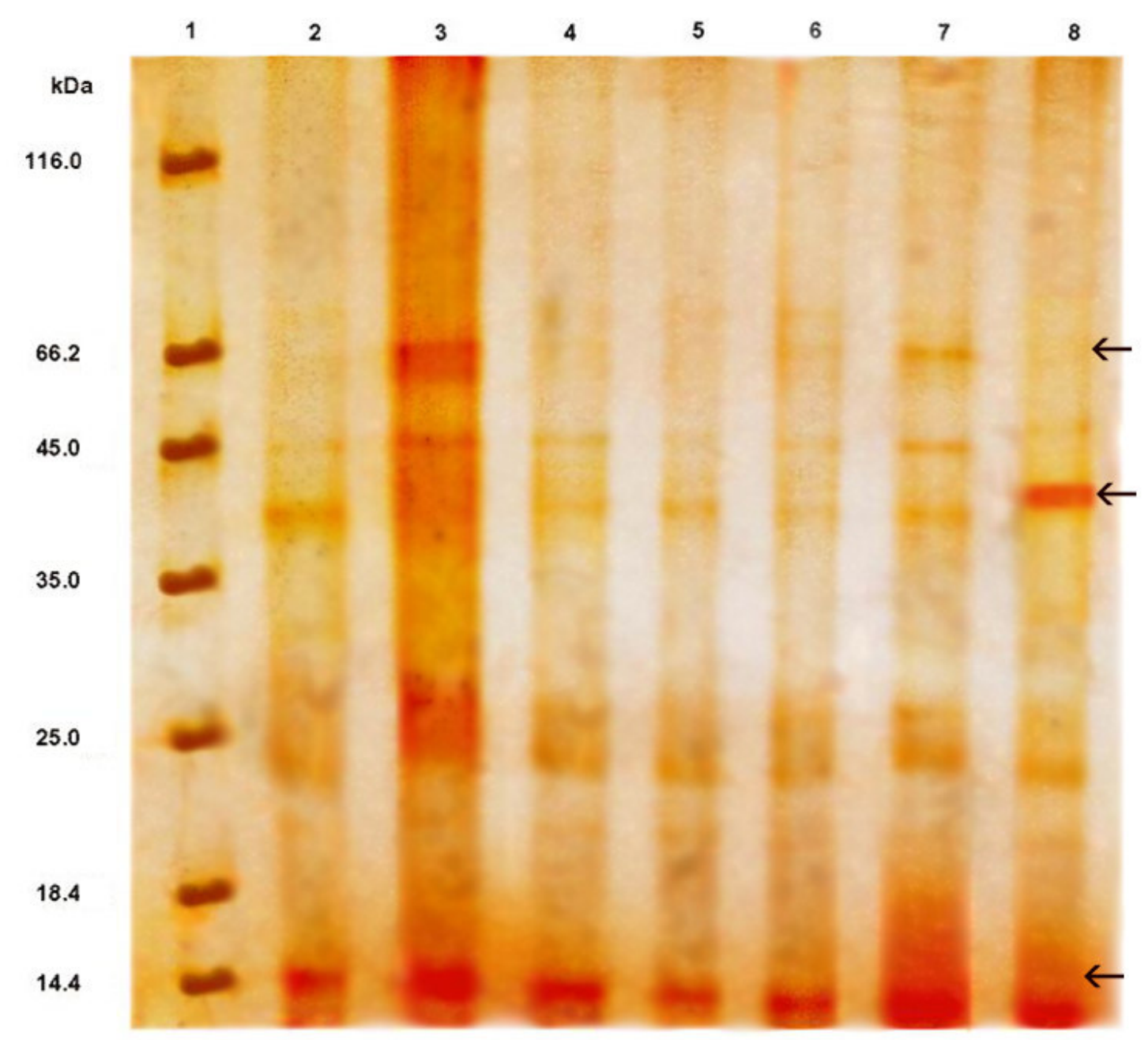

Figure 5. Polypeptide spectra (SDS-PAGE) of thermostable proteins in endosperm samples. Twenty $\mu g$ of total protein was loaded in each lane. Lane order as in Figure 4. Molecular mass markers are indicated on the left in $k D a$ 
The total proportion of thermostable polypeptides was greatest in the endosperm of high temperature treated seedlings. One highly intensive polypeptide band at $42 \mathrm{kDa}$ was found only in the $\mathrm{H}_{2} \mathrm{O}_{2}$ treated endosperms. The high temperature treatment elicited polypeptides with MW of 60 and $66 \mathrm{kDa}$. The same MW $66 \mathrm{kDa}$ polypeptide was also found as trace amounts in $\mathrm{ABA}$, sucrose and $\mathrm{H}_{2} \mathrm{O}_{2}$ treated endosperms.

In contrast to the endosperms, there was greater variation in the total number of polypeptide bands revealed in root samples.

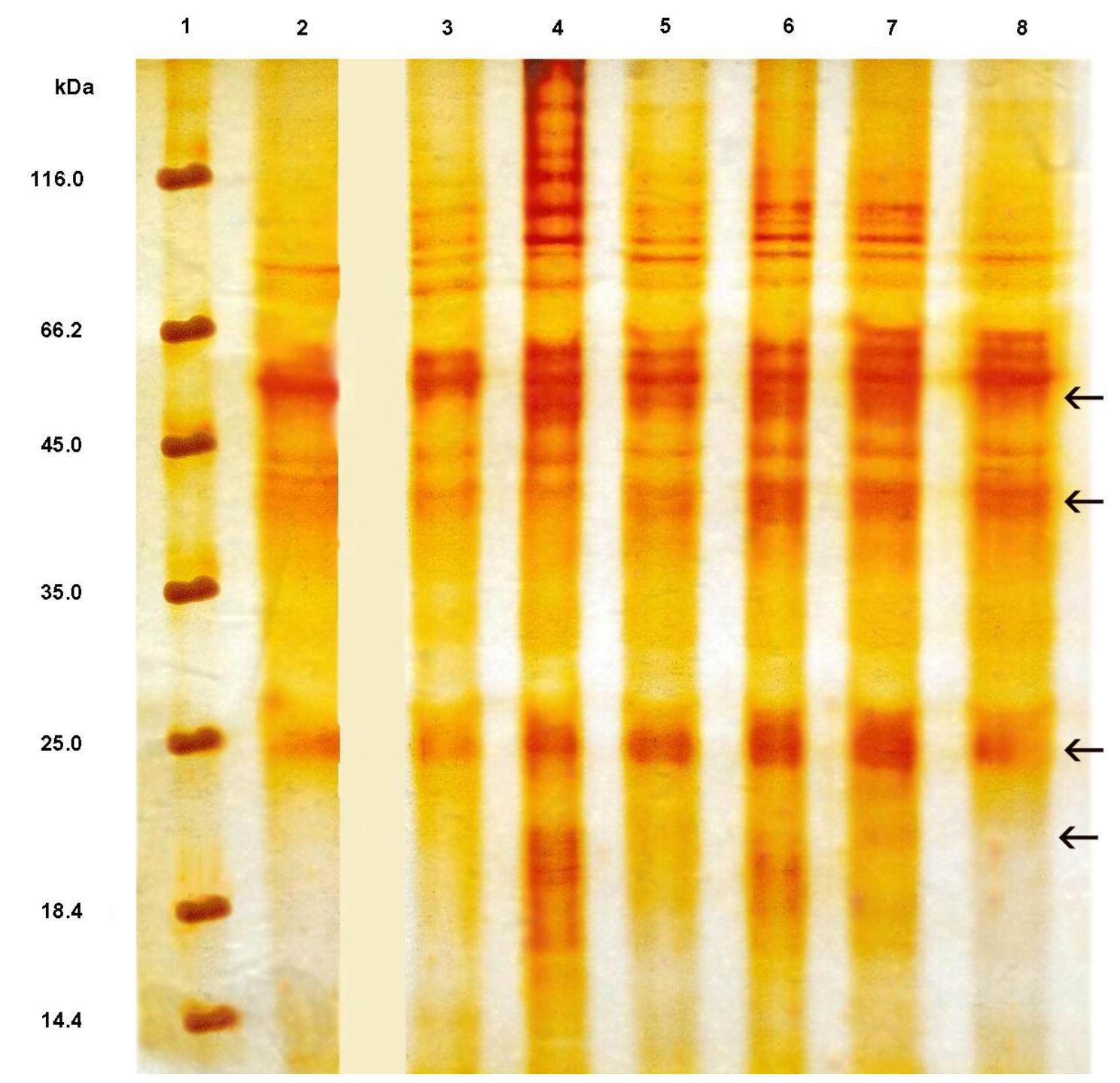

Figure 6. Polypeptide spectra (SDS-PAGE) of total soluble proteins in the roots of seedlings. Twenty $\mu \mathrm{g}$ of total protein was loaded in each lane. Lane order as in Figure 4. Molecular mass markers are indicated on the left in $\mathrm{kDa}$

In the roots of control seedlings six total polypeptide bands were revealed (Fig. 6), and were most intense at MW of $56 \mathrm{kDa}$. At high temperature 10 bands were detected and the band intensity pattern was most similar to the control sample. The greatest number (18-19) and the most intensive polypeptide bands were revealed in roots of low temperature germinated seedlings. Bands of particular note included a number above 80 $\mathrm{kDa}$, a group with MW between 60 and $52 \mathrm{kDa}$, a 25-kDa band and four polypeptides 
with MW between 20 and $17 \mathrm{kDa}$. Twelve bands were found in roots treated with $\mathrm{NaCl}$ during germination. Bands with MW between 60 and $52 \mathrm{kDa}$ and $25 \mathrm{kDa}$ were most intensive. In sucrose treated roots, 16-17 polypeptides stained, with those between 60$52 \mathrm{kDa}, 25 \mathrm{kDa}$ and 20-19 $\mathrm{kDa}$ being present in the greatest quantity. The same number of bands were present in the ABA treatment, but the spectra was dominated by bands at: 66-52 kDa, $42 \mathrm{kDa}, 27 \mathrm{kDa}$ and $25 \mathrm{kDa}$. Twelve bands were revealed for the $\mathrm{H}_{2} \mathrm{O}_{2}$ treatment, being most intensive at $\mathrm{MW}$ of $66-52 \mathrm{kDa}, 42 \mathrm{kDa}$ and $25 \mathrm{kDa}$. It is interesting to note that the highest molecular weight polypeptides $(>80 \mathrm{kDa})$ were present only in seeds germinated under stressed conditions, being most intense in low temperature treatment. In $\mathrm{NaCl}, \mathrm{ABA}$ and $\mathrm{H}_{2} \mathrm{O}_{2}$ treated roots a polypeptide with a $\mathrm{MW}$ of $66 \mathrm{kDa}$ was detected. Induction of polypeptides between 56-52 $\mathrm{kDa}$ occurred in the roots of low temperature, $\mathrm{NaCl}$, sucrose, $\mathrm{ABA}$ and $\mathrm{H}_{2} \mathrm{O}_{2}$ treated seeds (Fig. 6). Two bands (MW between 45-41 kDa) were present in $\mathrm{ABA}$, sucrose and $\mathrm{H}_{2} \mathrm{O}_{2}$ treated roots, that were more intensive compared to other stress treated seedlings, and were absent in the control. A $25 \mathrm{kDa}$ polypeptide in the roots from seedlings exposed to low temperature, $\mathrm{NaCl}, \mathrm{ABA}$ and sucrose was significantly more intensive compared to the control and high temperature treated roots. A significant difference between the low temperature stressed roots and other treatments was observed for polypeptides located in a zone at 20-17 $\mathrm{kDa}$. These polypeptides were absent in all other treatments except the sucrose.

\section{Discussion}

There was a higher total protein content in our endosperm samples exposed to low temperature, $\mathrm{NaCl}$, or sucrose stress compared to control samples. We also detected unusually high total protein in root samples exposed to a low temperature treatment of $10^{\circ} \mathrm{C}$ during germination.

In a previous study we established a retardation of germination rate and reduction of seedling growth as estimated by the reduced FW in all seedlings subjected to low and high temperature, sucrose, $\mathrm{ABA}, \mathrm{NaCl}$ and $\mathrm{H}_{2} \mathrm{O}_{2}$ treatment. There was a $94 \%$ decrease in growth of roots in low temperature stressed seedlings as compared to the control. The presence of sucrose, high temperature, $\mathrm{ABA}$ and $\mathrm{NaCl}$ suppressed root growth by $88 \%$, $87 \%, 78 \%$ and $53 \%$, respectively. In addition, $\mathrm{H}_{2} \mathrm{O}_{2}$ suppressed root growth by $43 \%$. There were no significant differences between endosperms of seedlings subjected to the stress factors studied [22].

A significant decrease of total protein content during the process of early germination has been established previously in wheat [15], and in triticale [23], [24] seeds germinated under stress- free conditions. In stressed seeds a delay in protein reserve mobilization occurs in maize [25] and pea [16]. These authors reported that the degradation of protein reserves during germination was closely associated with prevailing temperature. Of particular note was that no changes in polypeptide composition occurred in pea embryos imbibing at high temperature $\left(38^{\circ} \mathrm{C}\right.$ and $\left.40^{\circ} \mathrm{C}\right)$ [16]. A suggestion thus arose that a decrease in the activity of proteolytic enzymes may be a contributing factor to the poor germination observed under high temperature stress. Our results for total protein contrast with these observations in pea in that we noted a significant depression of protein degradation at low, not high, temperature in the roots of young seedlings and to a much lesser degree in endosperm tissue. Protein degradation in early germination process was well balanced with the synthesis of new 
polypeptides, which began during the initial hours of embryo imbibition [26]. We propose that the high protein content detected in roots at low temperature was due to the suppression of protein mobilization rather then to protein synthesis based on the fact that seedling growth under low temperature conditions was strongly reduced. This conclusion is based on two premises. Firstly that cold stress inhibits DNA replication, gene transcription and translation [27]. Secondly, Minamikawa et al. [28] demonstrated that the degradation of most of globulin proteins at the embryonic axis is likely to be dependent on de novo synthesis of proteolytic enzymes.

We observed high molecular weight polypeptides ( $>80 \mathrm{kDa}$ ) only in seeds germinated under stress conditions. In the control seeds they were absent. Chumikina et al., [24] revealed that under optimal conditions (control seedlings) at this stage of germination the same proteins had already been degraded.

We observed high qualitative and quantitative specificity between polypeptide spectra and stress treatments. Stress parameters we have previously investigated (growth and antioxidant enzymes, Bakalova et al. [22]) revealed high similarity between control and $\mathrm{H}_{2} \mathrm{O}_{2}$ treatment and also between low temperature and sucrose treatment. It is noteworthy that the lowest number of low intensive polypeptides was observed in sucrose. It could be noted that the polypeptides from first and second group were most intensive in the endosperm of $\mathrm{H}_{2} \mathrm{O}_{2}$ treatment compared with other treatments and also to other polypeptides.

We found polypeptides in the endosperms and roots of wheat germinated under stress conditions ranging from 150 to $14.4 \mathrm{kDa}$. Four grouping of polypeptides between 14.4 and $66.2 \mathrm{kDa}$ detected in endosperms and five groupings between 18 and $150 \mathrm{kDa}$ were noted in root samples. 72 hours after the onset of imbibition under normal conditions the mobilization of embryo reserves should be almost complete and mobilization of endosperm reserves just begining [14], [15], [24]. In stressed seedlings there were different amounts of high molecular weight polypeptides (Fig. 6) that could be due to delayed mobilization and this was especially well pronounced in the case of low temperature treatment. There is much data in the literature to indicate that embryos become self-supporting relatively early on in the germination process [28], [24] through the manufacture and utilization of their own protein reserves. Qualitative and quantitative changes in polypeptide composition in wheat embryos begin around 24 hours after the onset of germination when root growth has begun.[29]. Visible changes in the endosperm begin in triticale after about 96 hours of germination [24]. Our results show that the biochemical composition of roots and endosperms were shown to exhibit certain differences. The roots contained polypeptides of over $66 \mathrm{kDa}$, while the endosperm contained a low molecular polypeptide with MW $14.4 \mathrm{kDa}$ that was entirely absent in the root. The most significant difference however, was the induction of a 65 $\mathrm{kDa}$ polypeptide in stressed endosperms that was absent in the control

Our spectra of total polypeptides highlighted differences between treatments in both roots and endosperms. We found that the time course of protein mobilization is different depending on the particular stress factor applied. In particular we noted tissue specific responses to extreme temperatures. Low temperature stress elicited the greatest number and concentration of polypeptides in roots, and which coincided with a high total protein content observed in the roots. Polypeptide profiles in endosperms were most strongly affected by high temperature. This variance in response to high and low temperature according to tissue type is similar to the variable responses reported by Fowler and Tomashov [30] and Sung et al. [31]. The content of thermostable 
polypeptides in the endosperm of high temperature treated seedlings was greater than those germinated at low temperature. Our observations of an absence of thermostable proteins in the roots of 72 hour old seedlings concurs with the results found in other species such as soybean, where thermostable proteins in seedlings decreased and disappeared after 18 hours of germination [32].

One possible explanation for delayed protein mobilization in response to $\mathrm{ABA}$ stress is suggested by the data on cereals presented by Fincher [33]. The data suggest that ABA-induced proteins include inhibitors of key enzymes necessary for the germination process. ABA inducible genes could mediate a transient arrest in endosperm protein mobilization in response to unfavorable environmental conditions such as water, temperature and salt stress. We observed a total number of 6-8 thermostable polypeptides in our endosperm samples and a polypeptide with MW $25 \mathrm{kDa}$ was very intensive in stressed endosperms, especially in the high temperature treatment. Marian et al. [12] observed in Rhododendron species the same number of dehydrins (thermostable proteins) with MW between 25 and $73 \mathrm{kDa}$. Our data are consistent with their proposal for a key role of dehydrin with MW $25 \mathrm{kDa}$ in protecting Rhododendron leaves from freezing injury. Data on the correlation between $25 \mathrm{kDa}$ dehydrin accumulation and the level of freezing tolerance were also presented for other species like blueberry [34] and wheat [35]. Our data show that this dehydrin may play protective role in other stress factors like high salinity, high osmoticum, and high temperature.

The conclusions of this study are that low temperature stress elicited the greatest number and the most intensive total polypeptide spectra in the roots of treated seedlings. High temperature most strongly influenced the profile of thermostable polypeptides in the endosperm of seedlings. The time course of protein mobilization depended on the stress factors applied. The amount of a $25 \mathrm{kDa}$ polypeptide (dehydrin) increased in the roots of stressed seedlings. A thermostable polypeptide with a molecular weight of 42 $\mathrm{kDa}$ was found in $\mathrm{H}_{2} \mathrm{O}_{2}$ stressed samples that was highly intensive and probably constitutes a stress specific response like protector against oxidative stress.

\section{REFERENCES}

[1] Dose, K. (1980): Biochemie. - Springer Berlin, Heidelberg, New York.

[2] Vierstra, R.D. (1993): Protein degradation in plants. - Annual Review of Plant Physiology and Plant Molecular Biology 44: 385-410.

[3] Hieng, B., Ugrinovich, K., Sustar-Vozlich, J., Kidric, M. (2004): Different classes of proteases are involved in the response to drought of Phaseolus vulgaris L. cultivars differing in sensitivity. - Journal of Plant Physiology 161: 519-530.

[4] Bradford, K.J., Hsiao, T.C. (1982): Physiological responses to moderate water stress. Encyclopedia of Plant Physiology, New series. - Springer Verlag, Berlin.

[5] Pierre, M., Savoure, A. (1990): Effects of water stress and $\mathrm{SO}_{2}$ pollution on spruce endopeptidases. - Plant Physiology and Biochemistry 28: 95-104.

[6] Roy-Macauley, H., Zuily-Fodil, Y., Kidric, M., Pham Thi, Viera da Silva, J. (1992): Effect of drought stress on proteolytic activities in Phaseolus and Vigna leaves from sensitive and resistant plants. - Physiologia Plantarum 85: 90-96.

[7] Todd, G.W., Basler, E. (1965): Fate of various protoplasmic constituents in roughed wheat plants. - Phyton 22: 79-85. 
[8] Singh, G., Rai, V.K. (1982): Responses of two differentially sensitive Cicer arietinum L. cultivars to water stress: protein content and drought resistance. - Biologia Plantarum 24(1): 7-12.

[9] Close, T.J. (1996): Dehydrins: Emergence of a biochemical role of a family of plant dehydration proteins. - Physiologia Plantarum 97: 795-803.

[10] Close, T.J. (1997): Dehydrins: A commonalty in the response of plants to dehydration and low temperature. - Physiologia Plantarum 100: 291-296.

[11] Svenson, J., Ismail, A., Pavla, M., Close, T. (2002): Dehydrins. Sensing, signaling, and cell adaptation. - Elsevier Science B.V.

[12] Marian, C.O., Krebs, S.L., Arora, R. (2003): Dehydrin variability among rhododendron species: a $25-\mathrm{kDa}$ dehydrin is conserved and associated with cold acclimation across diverse species. - New Phytologist 161: 773-780.

[13] Rabbani, A.M., Maruyama, K., Abe, H., Khan, A., Katsura, K., Ito, Y., Yoshihara, K., Seki, M., Shinozaki, K., Yamaguchi-Shinozaki, K. (2003): Monitoring expression profiles of rice genes under cold, drought and high-salinity stresses and abscisic acid application using cDNA microarray and RNA gel-blot analyses. - Plant Physiology 133: 1755-1767.

[14] Bewley, J.D., Black, M. (1985): Seed: Physiology of Development and Germination. Springer-Verlag, Berlin.

[15] Zairov, C.Z. (1987): Accumulation and turnover of proteins in wheat grains. - Nauka, Alma-Ata.

[16] Gumilevskaya, N.A., Chumikina, L.V., Arabova, L.I., Zimin, M.V. (1993): Heat shock influence on the storage protein mobilization in axial organs of imbibing embryos of pea (Pisum sativum L.). - Russ. J. Plant Physiology 40: 110-115.

[17] Close, T.J., Fenton, R.D., Yang, A., Asghar, R., DeMasson, D.A., Crone, D.E., Meyer, N.C., Moonan, F. (1993): Dehydrin: The protein. Plant Responses to Cellular Dehydration During Environmental Stress. - American Society of Plant Physiologists, Rockville, MD.

[18] Lowry, O.H., Rosebrough, N.J., Farr, A.L., Randal, R.L. (1951): Protein measurement with the Folin phenol reagent. - Journal of Biological Chemistry 193: 265-275.

[19] Davis, B.J. (1964): Disc Electrophoresis-II: Method and Application to Human Serum Proteins. - Ann. N.Y. Acad. Sci. 15: 404-427.

[20] Laemmli, U.K. (1970): Cleavage of structural proteins during the assembly of the head of bacteriophage T4. - Nature 227: 680-685.

[21] Nesterenko, M.V., Tilley, M., Upton, J. (1994): A simple modification of Blum's silver stain method allows for 30 minute detection of proteins in polyacrylamide gels. - Journal of Biochemical and Biophysical Methods 28: 239-242.

[22] Bakalova, S.N., Nikolova, A., Nedeva, D.Y. (2004): Isoenzyme profiles of peroxidase, catalase and superoxide dismutase as affected by dehydration stress and ABA during germination of wheat seeds. - Bulgarian Journal of Plant Physiology 30(1-2): 64-77.

[23] Solov'eva, N.A., Sidel'nikova, L.I., Shaposhnikov, G.L., Evstigneeva, Z.G., Shatilov, V.R. (1998): Activity of enzymes responsible for the metabolism of nitrogen and carbon in germinating wheat seeds. - Applied Biochemistry and Microbiology 34(2): 189-192.

[24] Chumikina, L.V., Solovéva, N.A., Arabova, L.I., Sidellnikova, L.I., Lshaposhnikov, G., Malikov, V.F., Evstigneeva, Z.G., Shatilov, V.R. (1999): Changes in the composition of proteins and free amino acids and the activities of enzymes responsible for the metabolism of glutamine and malate in germinating triticale seeds. - Prikladnaja Biohimija and Mikrobiologija 35(6): 695-703.

[25] Riley, G.J.P. (1981): Effects of high temperature on the germination of maize (Zea mays L.). - Planta 151(1): 68-75.

[26] Bewley, J.D. (1982): Protein and nucleic acid synthesis during germination and early seedling growth in Encyclopedia of Plant Physiology.New Ser. - Plenum Press, N.Y. 
[27] Vorob'eva, L.I. (2004): Stressors, Stress reactions, and survival of bacteria: a review. Applied Biochemistry and Microbiology 40(3): 261-269.

[28] Minamikawa, T., Suzuki, Y., Koshiba, T. (1983): Metabolic changes in axes of germinating Vigna inoculata seeds as related to effects of removal of cotyledons. - Plant and Cell Physiology 24(8): 1361-1369.

[29] Illi, I.E., Koritov, M.V., Beznosov, M.V., Kozarenko, T.D. (1985): Studies on globulin proteins from wheat caryopsis at early stages of germination. - Physiology and Biochemistry of Cultivated Plants 17(1): 70-76.

[30] Fowler, S., Thomashov, M.F. (2002): Arabidopsis transcriptome profiling indicates that multiple regulatory pathways are activated during cold acclimation in addition to the CBF cold response pathway. - Plant Cell 14: 1675-1690.

[31] Sung, D.Y., Kaplan, F., Lee, K.J., Guy, Ch. L. (2003): Acquired tolerance to temperature extremes. - Trends in Plant Science 8(4): 179-187.

[32] Blackman, S.A., Wettlaufer, S.H., Obendorf, R.L., Leopold, A.C. (1991): Maturation proteins associated with desiccation tolerance in soybean. - Plant Physiology 96: 868874.

[33] Fincher, G.B. (1989): Molecular and cellular biology associated with endosperm mobilization in germinating cereal grains. - Annual Revue of Plant Physiology and Plant Molecular Biology 40: 305-46.

[34] Arora, R., Rowland L.J., Panta, G.R. (1997): Chill responsive dehydrins in blueberry: are they associated with cold hardiness or dormancy transitions. - Physiologia Plantarum 101: 8-16.

[35] Danyluk, J., Perron, A., Houde, M., Limin, A., Fowler, B., Benhamou, N., Sarhan, F. (1993): Accumulation of an acidic dehydrin in the vicinity of the plasma membrane during cold acclimation of wheat. - Plant Cell 10: 623-638. 